University of Nebraska - Lincoln

DigitalCommons@University of Nebraska - Lincoln

2018

On the shoulders of giants: A meta-review of strategic human resource management

Kaifeng Jiang

Jake G. Messersmith

Follow this and additional works at: https://digitalcommons.unl.edu/managementfacpub

Part of the Business Administration, Management, and Operations Commons, Management Sciences and Quantitative Methods Commons, and the Strategic Management Policy Commons

This Article is brought to you for free and open access by the Management Department at DigitalCommons@University of Nebraska - Lincoln. It has been accepted for inclusion in Management Department Faculty Publications by an authorized administrator of DigitalCommons@University of Nebraska - Lincoln. 


\title{
On the shoulders of giants: A meta-review of strategic human resource management
}

\author{
Kaifeng Jiang ${ }^{1}$ and Jake Messersmith ${ }^{2}$
}

\author{
1 Department of Management and Human Resources, \\ Fisher College of Business, The Ohio State University, Columbus, OH \\ 2 Department of Management, College of Business, \\ University of Nebraska-Lincoln, Lincoln, NE \\ Correspondence - Kaifeng Jiang, jiang.1788@osu.edu
}

\begin{abstract}
Recent years have witnessed significant growth in the field of strategic HRM. This article summarizes the literature in this field by conducting a meta-review, a review of the reviews that have covered various topics of strategic HRM. In doing so, the authors highlight theoretical frameworks and empirical findings of studies in the field over the past three decades, identify methodological issues and challenges in the previous research, and discuss recent trends in the field of strategic HRM. The author concludes by suggesting some interesting and important directions for future work.
\end{abstract}

\section{Introduction}

As HRs continue to play an increasingly important role in contemporary organizations, strategic HRM has become a distinct field of study through its evolution over the last 30 years. Jackson, Schuler, and Jiang

\footnotetext{
Published as: Kaifeng Jiang \& Jake Messersmith (2018) On the shoulders of giants: A metareview of strategic human resource management, The International Journal of Human Resource Management, 29:1, 6-33.

doi: $10.1080 / 09585192.2017 .1384930$

Copyright (c) 2017 Informa UK Limited, Taylor \& Francis Group. Used by permission. Published 24 October 2017.

Supplemental data for this article is attached to the archive record.
} 


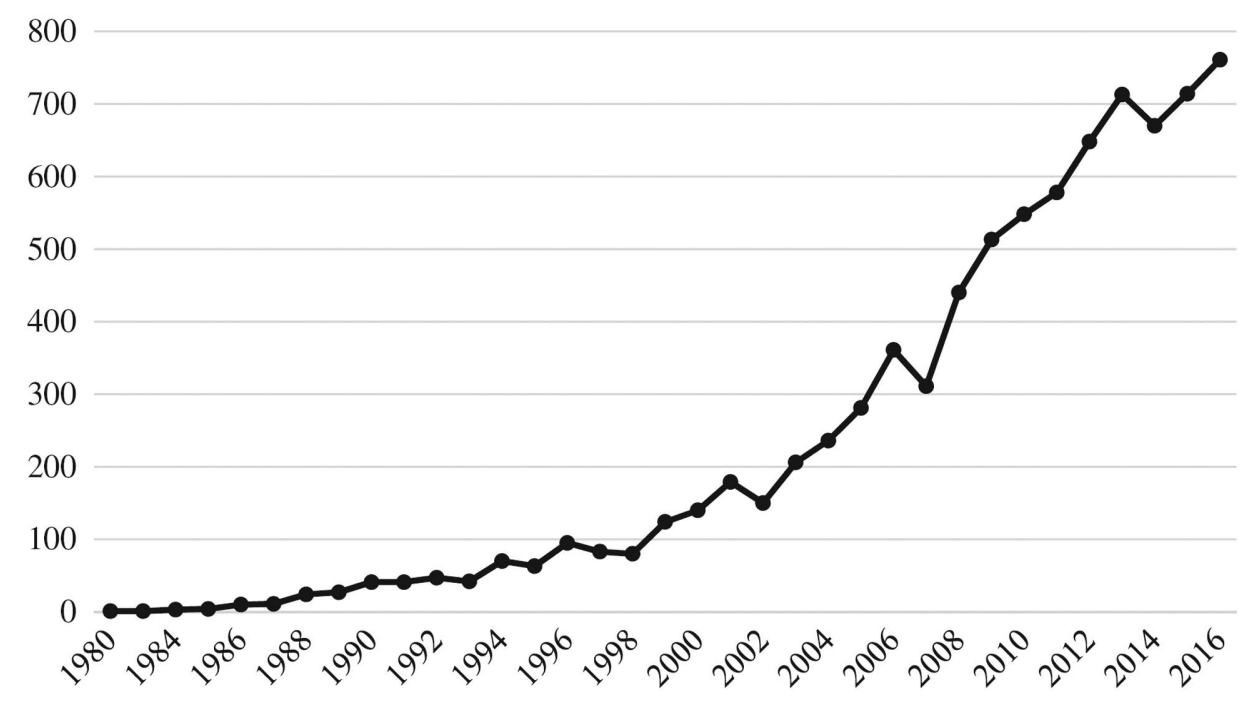

Figure 1. Number of articles per year including the term of 'strategic human resource management' from 1980 to 2016. Source: Scopus, 1980-2016.

(2014) defined strategic HRM scholarship as 'the study of HRM systems (and/or subsystems) and their interrelationships with other elements comprising an organizational system, including the organization's external and internal environments, the multiple players who enact HRM systems, and the multiple stakeholders who evaluate the organizations' effectiveness and determine its long-term survival' (p. 4). Consistent with other scholars' definitions (e.g. Delery \& Shaw, 2001; Wright \& McMahan, 1992), Jackson et al.'s definition emphasizes HRM systems and their relationships with other elements of organizations including organizational performance and effectiveness, which differentiates strategic HRM from traditional HRM research.

Strategic HRM has gained an increasing amount of attention in management research and among practitioners in the past few decades. As shown in Figure 1, the strategic HRM literature has expanded massively since its birth in the 1980s. The Scopus database lists over 8126 publications including the term 'strategic human resource management' from 1980 to 2016. Scholars from over 120 countries were involved in those papers that were published in over 150 journals. In Google Scholar, there are about 32,000 publications 
related to the topic of strategic HRM and this number is increasing at an accelerating rate. In order to understand what has been done in the past and what can be done in the future to advance the field of strategic HRM, it is critical to conduct a systemic review of previous research in this area.

There have been a number of important conceptual (e.g. Guest, 1997, 2011, 2017; Jackson et al., 2014; Lepak, Liao, Chung, \& Harden, 2006; Paauwe, 2009; Wright \& Boswell, 2002; Wright \& Ulrich, 2017) and meta-analytic reviews of strategic HRM (e.g. Combs, Liu, Hall, \& Ketchen, 2006; Jiang, Lepak, Hu, \& Baer, 2012; Rabl, Jayasinghe, Gerhart, \& Kühlmann, 2014; Subramony, 2009). However, as shown in Figure 1, the field of strategic HRM has grown quickly in the past decade as $70 \%$ of the total articles in the field (5896 out of 8216 ) have been published between 2007 and 2016. Therefore, there is a need for an updated review to cover the key findings from previous reviews and emerging trends and topics in recent empirical research. With this objective, the current paper takes a 'meta-review' approach to summarize findings of previous conceptual and empirical review articles of strategic HRM. The meta-review approach is an effective way to understand the status quo in the strategic HRM paradigm, given the extensive body of work in this area. This approach also goes beyond a traditional review by revealing the theoretical and methodological issues pervading this field, and, thus offers a basic and comprehensive understanding of the status quo and main challenges of the field. More specifically, we review 68 reviews that have covered various theories and topics of strategic HRM to identify the primary theoretical frameworks used in strategic HRM research, summarize the general findings of empirical work, and discuss the important methodological issues (e.g. measurement issues and research design). We also refer readers to exemplar reviews when discussing particular points. Moreover, we complement the meta-review by examining 183 empirical studies of strategic HRM. When reviewing the empirical studies, we focus on the changes in research topics over time and especially highlight the emerging trends in the past decade. In the end, we discuss some interesting and important topics for future studies of strategic HRM. 


\section{Reviews on strategic HRM}

\section{Search for prior reviews of strategic $H R M$}

We searched the EBSCO Business Source Premier, Web of Science, and Scopus databases for academic articles and book chapters containing the terms 'strategic human resource management' and 'review' in the title, abstract, or keywords. We used two criteria to include the conceptual and meta-analytic reviews in this meta-review. First, we included articles with the primary purpose of summarizing and synthesizing previous studies. We excluded theoretical articles that focused on developing theoretical models and propositions (e.g. Jiang et al., 2012a; Lepak \& Snell, 1999; Paauwe \& Boselie, 2003). Second, we included review articles about HRM systems and their relationships with other variables and excluded those about individual HRM practices (e.g. Kooij, Jansen, Dikkers, \& De Lange, 2010) and international HRM (e.g. Dickmann \& Müller-Camen, 2006; Schuler, Budhwar, \& Florkowski, 2002; Schuler \& Tarique, 2007). These two criteria resulted in 68 review articles about strategic HRM including 64 conceptual reviews and 4 meta-analyses. We coded conceptual reviews based on the theoretical framework/ perspectives and methodological issues covered in the review articles. We did not code the meta-analytic reviews and only briefly discuss their main findings in the following section.

\section{Theoretical foundations of strategic HRM}

The relationship between HRM systems and organizational effectiveness has been considered the fundamental and defining research question in strategic HRM (Jackson et al., 2014). Scholars have applied a number of theories to explain why, how, and when HRM systems are related to organizational outcomes. We coded the theories discussed in prior conceptual reviews and identified more than 20 theories or theoretical perspectives (see Table 1). The theories frequently mentioned in prior reviews (at least in 10 articles) include the resource-based view, human capital theory, the behavioral perspective, the ability-motivation-opportunity (AMO) framework, and social exchange theory. 
Table 1. Summary of strategic HRM theories in prior reviews.

The resource-based view argues that valuable, rare, inimitable, and nonsubstitutable resources can serve as potential sources of sustainable competitive advantage for firms (Barney, 1991; Wernerfelt, 1984). Based on this perspective, several scholars have theorized why HRs or HRM systems can meet the four criteria and, thus, become a potential source of sustainable competitive advantage (e.g. Lado \& Wilson, 1994; Wright, Dunford, \& Snell, 2001; Wright, McMahan, \& McWilliams, 1994). These theoretical works have set the basis for applying the resource-based view to strategic HRM research and many empirical studies draw upon this theory to explain the positive relationship between HRM systems and organizational performance. Although the resource-based view has become a guiding paradigm for strategic HRM research, this theory has received recent criticism. For example, Lepak, Takeuchi, Erhardt, and Colakoglu (2006) noted that researchers have not fully examined how HRM systems may result in HRs that meet the four criteria of sustainable competitive advantages. Kaufman 
(2015b) also identified several problems of using the resource-based view in strategic HRM research. We refer scholars who are interested in these critiques to the above-cited articles for more details.

Related to the resource-based view, human capital theory considers human capital to be a firm-level resource that can contribute to firmlevel performance and generate economic value (Barney \& Wright, 1998; Wright \& McMahan, 2011). However, different from other types of resources, human capital is owned by employees and can be transferred to other firms if employees leave. Therefore, it is critical for firms to use HRM systems to enhance existing levels of human capital (e.g. attracting and training employees) and to prevent the loss of their human capital investments to other firms (e.g. by motivating and retaining employees). Human capital theory has been applied to several topics in strategic HRM, such as the HR architecture (Lepak \& Snell, 1999, 2002) and the relationship between HRM systems and organizational performance (e.g. Kehoe \& Collins, in press; Takeuchi, Lepak, Wang, \& Takeuchi, 2007). Several recent reviews focus on understanding the cross-level emergent processes through which the human capital of individual employees becomes strategically valuable unit-level human capital (e.g. Nyberg, Moliterno, Hale, \& Lepak, 2014; Ployhart \& Moliterno, 2011; Ployhart, Nyberg, Reilly, \& Maltarich, 2014; Wright \& McMahan, 2011), which represents a direction for continued research in strategic HRM scholarship.

If the resource-based view and the human capital theory explain why HRs and HRM systems are important, the behavioral perspective emphasizes how HRM systems can help organizations achieve their strategic goals. Rooted in role theory, the behavioral perspective argues that organizations require desired role behaviors of employees to meet the challenges of internal and external environments and HRM systems can contribute to organizational effectiveness by managing and controlling such desirable behaviors (Jackson \& Schuler, 1995; Jackson, Schuler, \& Rivero, 1989; Schuler \& Jackson, 1987). The behavioral perspective provides the theoretical foundation for examining the mediating mechanisms of the relationship between HRM systems and organizational outcomes. Scholars often refer to the behavioral perspective for identifying specific mediators and exploring how HRM systems influence organizational effectiveness by affecting employee behaviors (e.g. Becker \& Huselid, 1998; Delery \& Shaw, 2001; Guest, 1997; Jiang et al., 2012b). 
The AMO framework is considered a variant of the behavioral perspective (Jackson et al., 2014). This framework argues that individual performance is a function of an employee's abilities, motivation, and opportunity to perform (Gerhart, 2007). HRM systems can contribute to firm performance by enhancing the three components of employee performance (Jiang et al., 2012a). Similar to the behavioral perspective, the AMO framework has been widely used in strategic HRM research to explain the mediating processes through which HRM systems are related to organizational performance (e.g. Becker \& Huselid, 1998; Delery \& Shaw, 2001; Guest, 1997). Research has also found that HRM systems can be divided into sub-dimensions (i.e. skill-enhancing, motivation-enhancing, and opportunity-enhancing HRM practices) based on the AMO model and different components of HRM systems influence firm performance by affecting employee outcomes in different ways (Jiang et al., 2012b).

As researchers become more interested in understanding how HRM systems influence organizational performance by affecting employee attitudes and behaviors, social exchange theory has been increasingly applied to strategic HRM research. Social exchange theory is based on Gouldner's (1960) norm of reciprocity and Blau's (1964) work on social exchange relationships. This theory suggests that individuals who receive benefits from one party tend to respond in kind. HRM systems intended to benefit employees may be considered as the organization's investment in employees; employees may then reciprocate with positive attitudes and behaviors toward the organization in order to maintain the exchange relationship. Research has found support for this theory by showing that HRM systems can enhance organizational performance by enhancing employees' social exchange relationship with organizations (Takeuchi et al., 2007) and their positive attitudes and behaviors in the workplace (Messersmith, Patel, Lepak, \& Gould-Williams, 2011).

In addition to the theories summarized above, prior review articles have also identified a number of other theoretical perspectives, such as institutional theory, organizational climate theory, social capital theory, and attribution theory (see Table 1). All of these theories have been used to explain different research questions in the strategic HRM literature. For example, institutional theory is helpful for understanding the adoption of HRM systems in organizations based upon a firm's context. According to Wright and McMahan (1992), the use of HRM 
systems may not always result from rational decision-making based on an organization's strategic goals. Instead, internal and external factors of the organization may force it to adopt certain HRM practices in order to attain a sense of legitimacy. In addition, attribution theory has been recently integrated into the strategic HRM literature to understand why employees have different reactions to the same HRM systems. Nishii, Lepak, and Schneider (2008) found that employee attributions regarding the purpose of implementing HRM systems can influence their collective behaviors and unit performance. Due to the length of this review, we cannot introduce each of the theories listed in the Table in detail. For those who are interested in learning more about these theories, we refer them to the supplementary material ${ }^{1}$ and recommend other reviews with more of a focused concentration on the theoretical foundations of strategic HRM (e.g. Boselie, Dietz, \& Boon, 2005; Fleetwood \& Hesketh, 2008; Wright \& McMahan, 1992). Future research may consider some of the less frequently applied theoretical frameworks to further advance the field and improve understanding of the processes underlying strategic HRM.

\section{Empirical findings of strategic HRM}

Although most of the conceptual reviews of strategic HRM have summarized the results of empirical studies, we base our discussion of empirical findings of strategic HRM on the four meta-analytic reviews (Combs et al., 2006; Jiang et al., 2012b; Rabl et al., 2014; Subramony, 2009) that have been completed. All four of the meta-analyses examined the relationships between HRM systems and organizational outcomes. Combs and colleagues (2006) conducted the first meta-analysis of strategic HRM and found positive relationships between high-performance work systems (HPWSs) and organizational performance. They also examined how the main effect of HPWSs is moderated by the types of industry and the types of performance outcomes. Combs et al. (2006) has been widely cited to support the positive relationship between HRM systems and organizational outcomes. Subramony (2009) drew upon the AMO model to categorize HRM practices into three HRM bundles (e.g. skill-enhancing, motivation-enhancing, and empowerment- enhancing HRM practices). He focused on comparing the effect sizes of individual practices, HRM bundles, and HRM systems 
on organizational outcomes and found that HRM bundles have stronger relationships with organizational outcomes than individual HRM practices and are related to organizational outcomes more strongly than, or as strongly as, HRM systems. Subramony's (2009) findings highlight the importance of categorizing HRM practices into bundles aimed at enhancing specific characteristics of human capital. Moreover, Rabl and colleagues (2014) focused on the moderating effects of national factors on the relationship between HPWSs and business performance. They found that the positive relationship between HPWSs and business performance was more positive in countries with a tightly-knit national culture that is more consistent with HPWSs (e.g. low power distance or high performance-orientation). Their findings highlight the importance of national culture in understanding the relationship between HPWSs and business performance.

Different from the above three meta-analyses, Jiang and colleagues (2012b) examined the mediating mechanisms of the relationship between HRM practices and financial performance. They also drew upon the AMO model to categorize HRM practices into three policy domains and found that the skill-enhancing HRM policy domain has a stronger relationship with human capital and a weaker relationship with employee motivation than motivation-enhancing and opportunity- enhancing HRM policy domains. This finding reveals that the components of HRM systems may affect outcomes in different ways. Another contribution of Jiang et al.'s (2012b) work is that they found the two employee outcomes mediate the effects of HRM systems on organizations' operational and financial performance.

Taken together, the meta-analytic reviews have provided substantial evidence for the positive relationship between HRM systems and different types of organizational outcomes and have identified important moderators of this relationship across levels. They also provide some preliminary results for the mediating mechanisms of the HRM systems-performance outcomes relationship. At the same time, the meta-analyses also leave opportunities for future quantitative reviews; for example, all of the meta-analytic reviews thus far have been focused on the relationship between HRM systems and performance outcomes. It is also important to understand what factors are related to the adoption of HRM systems in organizations, such as organizational characteristics and environmental contexts. Moreover, 
those meta-analytic reviews were largely based on bivariate correlations between HRM systems and organizational outcomes. Future research can use partial correlation coefficients to verify the findings of previous meta-analyses as enough studies become available that provide sufficient information from which partial correlations can be extracted. Compared with traditional meta-analytic reviews, meta-analyses based on partial correlations can estimate the main relationship while holding other factors constant and, thus, provide more rigorous examinations on the relationship between HRM systems and organizational outcomes. In addition, Jackson et al.'s (2014) qualitative review found inconsistency in the results of moderating effects (e.g. the moderating effect of business strategy). Future meta-analyses are also needed to systematically synthesize the moderating effects on the HRM systems-performance outcomes relationship and reconcile the mixed findings in the literature.

\section{Methodological issues of strategic HRM}

In addition to reviewing the theoretical foundations and empirical findings of strategic HRM, many review articles have also discussed methodological issues in this area. We coded the commonly discussed methodological issues into five categories: measurement of HRM systems, measurement of performance outcomes, level of analysis, research design, and missing variables (see Table 2). In the current review, we mainly discuss issues related to the measurement of HRM systems, as this has drawn the most attention from prior reviews and is closely related to other methodological issues. For scholars who are interested in other methodological concerns, we suggest they refer to several previous reviews, such as: Rogers and Wright (1998) in relation to measurement of performance outcomes; Jiang, Takeuchi, and

Table 2. Summary of methodological issues of strategic HRM in prior reviews. 
Lepak (2013) and Peccei and Van De Voorde (in press) regarding levels of analysis issues; Gerhart (2005), Wall and Wood (2005), and Wright (2003) about research design; and Becker and Huselid (2006) and Wright and Haggerty (2005) relating to missing variables.

Even though researchers have reached an agreement that HR systems are a bundle of practices, there is much less agreement on how these systems are conceptualized and operationalized (e.g. Becker \& Gerhart, 1996; Lepak, Liao et al., 2006). The lack of consensus regarding components of HR systems makes it difficult to accumulate and compare the findings of HRM systems from different studies. Several problems have been discussed in previous reviews. First of all, researchers need to recognize that no single HR system can be adopted to manage all kinds of employees in an organization. Several researchers have suggested that organizations use different HR practices to manage different types of employees, due to their unique contributions to organizational goals (e.g. Lepak \& Snell, 1999, 2002; Tsui, Pearce, Porter, \& Tripoli, 1997). In this case, it is important for strategic HRM researchers to first specify what types of employees are covered by the HRM systems before they develop particular practices to represent the systems. For example, Chuang and Liao (2010) focused on HRM systems for managing customer-contact employees. Gong, Law, Chang, and Xin (2009) examined HRM systems that apply to middle managers. Focusing on a particular job group of employees allows researchers to carefully select the appropriate practices that apply to particular employees. This may provide more accurate information than defining HRM systems solely through identifying a set of practices (Boxall \& Macky, 2009). Related, the practices of HRM systems may also vary depending on the organizations' purposes in utilizing HRM systems. For example, Collins and Clark (2003) proposed a HRM system intended to build top management teams' social network. Zacharatos, Barling, and Iverson (2005) proposed a HRM system for occupational safety. Liao, Toya, Lepak, and Hong (2009) developed a HRM system to enhance service performance and customer satisfaction. This line of thinking suggests that, to precisely conceptualize HRM, researchers need to design HRM systems for specific organization objectives and needed role behaviors.

Second, after determining the coverage and purpose of an HRM system, research needs to consider which practices should be included in 
the HRM system. Recent reviews have shown that hundreds of HRM practices have been used in previous research and the specific practices included in HRM systems vary dramatically from one study to another (Combs et al., 2006; Lepak et al., 2006; Posthuma, Campion, Masimova, \& Campion, 2013). Instead of randomly selecting HRM practices from a laundry list, several scholars have suggested adopting a theoretical framework to guide the choice of practices. For example, the AMO model provides a framework for researchers to categorize different HRM practices into three bundles (e.g. Boxall \& Purcell, 2008; Jiang et al., 2012a; Lepak et al., 2006). Another framework is the employee-organization relationship (Tsui et al., 1997). Researchers have used this framework to categorize HRM practices into HRM inducements and investments and expectation-enhancing practices (e.g. Gong et al., 2009; Shaw, Dineen, Fang, \& Vellella, 2009).

Third, beyond the main components included in an HRM system, researchers also need to decide at which level they should measure the system. The 'level' here refers to the structural order within HRM systems, such as HRM philosophy, HRM policies, and HRM practices (Schuler, 1992). According to Wright and Boswell (2002), HRM policies represent 'the firm or business unit's stated intentions about the kinds of HR programs, processes, and techniques that should be carried out in the organization' (p. 263). Focusing on HRM policies allows the comparisons in terms of how people are managed across organizations, regardless of the practices chosen to implement those policies. However, policies cannot reflect the actual practices implemented in the organizations, so focusing on HRM policies may lead to inaccurate evaluations of HRM systems in organizations (Nishii \& Wright, 2008). In contrast, HRM practices consist of the actual programs, processes, and techniques that are operationalized in workplaces. Therefore, focusing on HRM practices may increase measurement accuracy. But the challenge of measuring HRM systems at the practice level lies in the fact that there are so many practices in place and it is not easy to decide which ones should be used to measure HRM systems. Regarding the dilemma, Lepak and Shaw (2008) suggested that researchers 'conceptualize HR systems accurately in terms of level and to develop measures that capture the level appropriately' (p. 1491).

Fourth, once researchers decide the level (e.g. policies or practices) composing a HRM system, they need to consider how to use questions 
or items to appropriately measure the HRM system. Strategic HRM researchers often use two types of questions: descriptive and perceptive questions. Descriptive questions ask respondents to report objective information (e.g. existence, or percentage) about the HRM policies or practices used in an organization. For example, in the early work strategic HRM, scholars (e.g. Arthur, 1992; Huselid, 1995) often used questions like 'What percentage of front-line employees received training beyond that mandated by government regulations in the last 12 months?' On the other hand, some other researchers adopted perceptive items to reflect the extent to which HR policies or practices are used in the organization. Sample questions include 'to what extent do you agree that this organization selects the best all-around candidates when recruiting employees?' It may be premature to conclude which approach provides more reliable and accurate information about HRM systems, as both approaches have their own merits. From the management perspective (e.g. HRM managers, executives), the descriptive approach is more likely to yield accuracy and agreement among respondents because the information is more observable and objective (Klein et al., 2001). However, Nishii and Wright (2008) argued that there might be a gap between actual HRM practices and perceived HRM practices. In this case, the perceptive measures are more likely to capture informants' perceptions (e.g. employees) of HRM systems which actually influence their reactions to those practices. To determine which approach should be used to measure HRM systems, researchers have suggested carefully choosing the informants who have the best knowledge to answer the questions about HRM systems and collecting information from multiple informants when it is possible to improve the reliability and accuracy of the measurement of HRM systems (Gerhart et al., 2000; Huselid \& Becker, 2000; Wright et al., 2001b).

Fifth, previous reviews have also discussed how to combine the scores of HRM policies or practices to reflect HRM systems after collecting the information. Most of the empirical research adopts an additive approach to calculate the total score of HRM systems. Researchers use this additive approach for two primary reasons. The first reason is related to the equifinality argument that different combinations may yield the same results. According to the equifinality argument, HRM systems may be equivalent in motivating employees in an organization 
offering high pay and high benefits only and in one offering high pay and high job security only (Shaw et al., 2009). In this case, researchers often use descriptive methods to measure HRM systems and average the standardized scores from different HRM practices. Second, some researchers use the results of factor analysis or high internal reliability to justify the addition of scores of HRM practice measures. However, the additive approach may not appropriately capture the internal relationships among HRM practices. First, the additive approach does not take the synergy among HRM practices into account. This encourages future researchers to explore the internal relationships among different HRM practices and provides some theoretical argument and empirical evidence for using a synergistic approach in strategic HRM research. Second, the additive approach implicitly assumes the equal contribution of each HRM practice and, thus, does not consider the weight of different practices within HRM systems. Recently, Lepak and Boswell (2012) proposed a concept of the saliency of HRM practices, which reflects individual preferences of different HRM practices, such that HRM practices may signal to employees their relative importance as being valued or not in their organization. In this case, the additive approach may overestimate the effects of some practices but underestimate the impact of others. Future research is encouraged to explore the concept of HR saliency and how HRM saliency influences the combination of scores of HRM systems.

This issue is also related to the nature of the HRM system construct itself and whether it is best studied as a formative construct or a reflective construct. According to MacKenzie et al. (2005), a formative model indicates that the measured policies or practices together form the whole HRM system. Each of these practices capture a unique aspect of the concept of HRM systems not captured by the others and none of them can reflect HRM systems in isolation (Jiang et al., 2012a). High internal reliability is not required for the formative model because different HRM practices are not expected to highly correlate with one another. In contrast, a reflective model suggests that HRM system measures such as high-performance work systems and high-commitment work systems be considered to be latent constructs indicated by specific HRM practices. In this case, high internal reliability is needed to justify the measure of HRM systems, because all the HRM system components are treated as interchangeable indicators 
of the latent construct of HRM systems. Research has shown that the choice of measurement model may change the conclusion of the focal construct's relationships with other variables (e.g. Law \& Wong, 1999). Therefore, strategic HRM scholars need to carefully consider the relationship between the construct and questions about HRM systems and choose an appropriate way to combine the scores of HRM practices to represent HRM systems. One possible solution is to consider specific questions within each HRM policy (e.g. comprehensive training) as reflective measures of the HRM policy and treat the HRM policies as facet constructs causing the formative construct of HRM systems (Edwards, 2011; Jiang et al., 2012a).

\section{Recent trends of strategic HRM}

To complement the review of prior review articles of strategic HRM, we also searched for empirical studies examining the relationships between HRM systems and performance outcomes. By doing so, we intend to highlight how the field of strategic HRM has evolved since its origin and identify some emerging themes in the past ten years. When we searched for articles, we only included those examining HRM systems at the unit level of analysis as this is consistent with the definition of strategic HRM scholarship (Jackson et al., 2014). But we included articles studying outcomes at both the individual level and the unit level. The search from primary databases (e.g. EBSCO and Web of Science) resulted in a final sample of 183 empirical studies. ${ }^{2}$

We coded the empirical articles on three factors - levels of analysis, research models, and research designs. First, the levels of analysis indicate whether a study examines the relationships between HRM systems and outcomes at a single level (e.g. firms and business units) or across levels. As shown in Figure 2, the unit-level analysis has dominated strategic HRM research during the past 20 years because researchers have been devoted to demonstrating the influence of HRM systems on organizational outcomes. However, scholars have become increasingly interested in multilevel research in the strategic HRM domain since the late 2010s. Interest in this multilevel approach has been driven by the development of multilevel methodology and researchers' interest in understanding employees' perceptions 


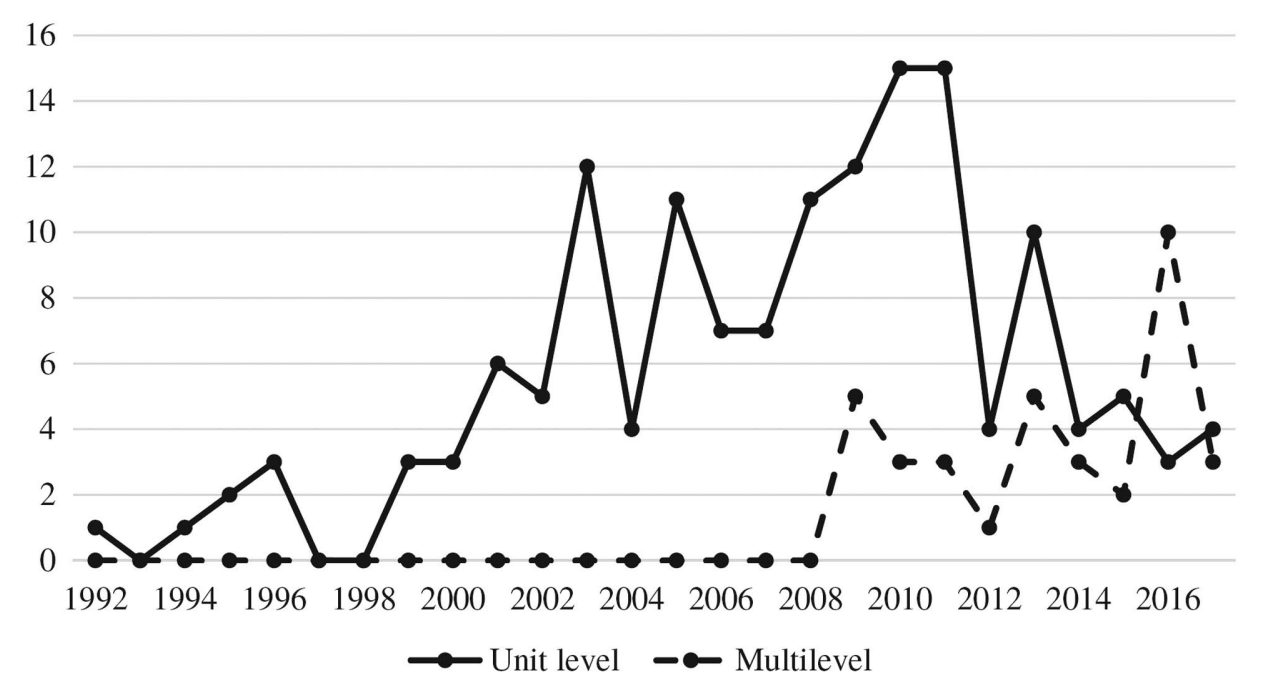

Figure 2. Numbers of Strategic HRM Studies by Levels.

of and reactions to HRM systems. Liao et al. (2009) and Takeuchi et al. (2009) are two exemplar articles of applying multilevel methods to strategic HRM research to understand the cross-level influence of HRM systems on individual-level outcomes. Peccei and Van De Voorde (in press) have recently reviewed the application of multilevel paradigm in strategic HRM research and offered some best practices for conducting multilevel research in strategic HRM.

Second, we coded whether an empirical study involved a moderation test or a mediation test or simply examined the main effect of HRM systems on outcomes. As shown in Figure 3, in the early stage of strategic HRM research, a large proportion of studies focused on the main effect of HRM systems. However, researchers have greatly extended the strategic HRM research by examining the moderators and mediating mechanisms of the relationship between HRM systems understanding when and how HRM systems are related to performance outcomes in organizations. Jackson and colleagues (2014) have offered a comprehensive review of the moderators and the mediators examined in previous research.

Third, we coded whether an empirical study used a cross-sectional design, a time-lagged design, or a longitudinal design. The cross-sectional design refers to collecting HRM systems and performance outcomes information at the same time, while a time-lagged design refers to collecting performance outcomes at a time after collecting the 


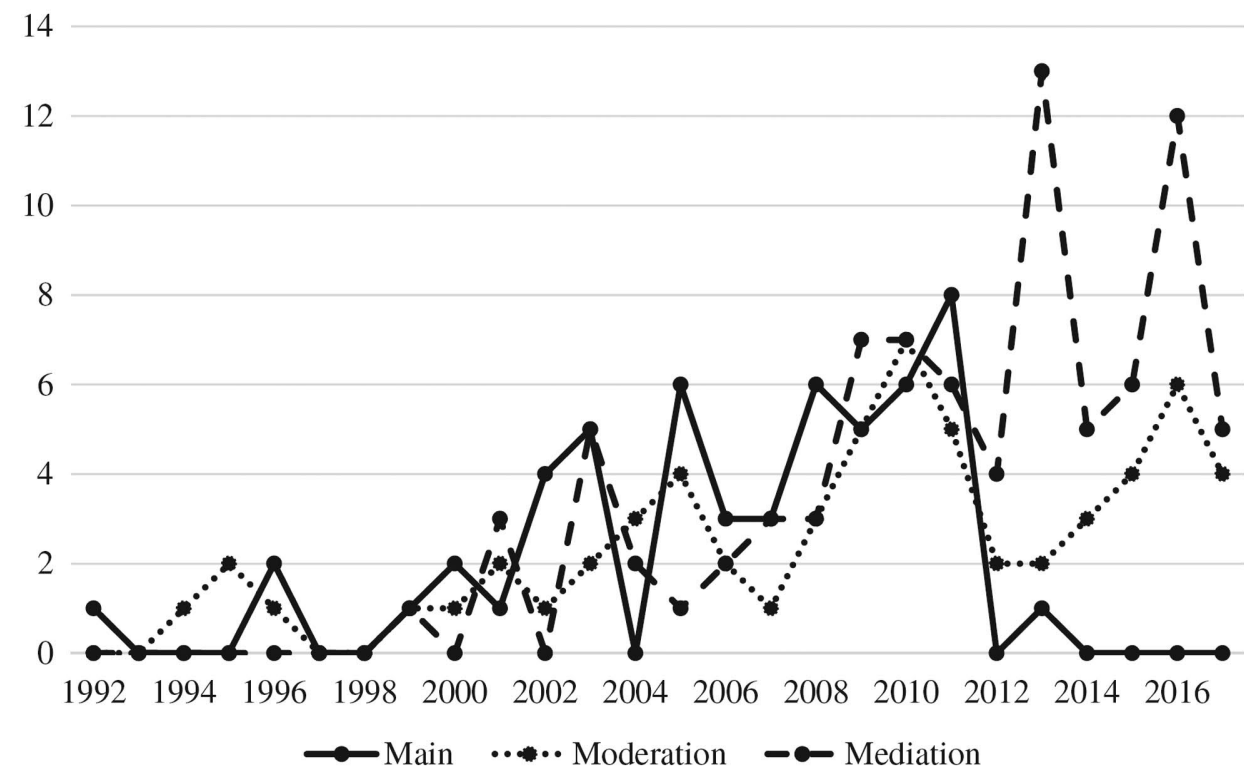

Figure 3. Numbers of Strategic HRM Studies by Research Models.

information of HRM systems. Different from these two, a longitudinal design refers to collecting repeated measures of HRM systems and performance outcomes at multiple time points. As shown in Figure 4, our coding results are consistent with Wright et al.'s (2005), that most of strategic HRM studies have adopted a cross-sectional design.

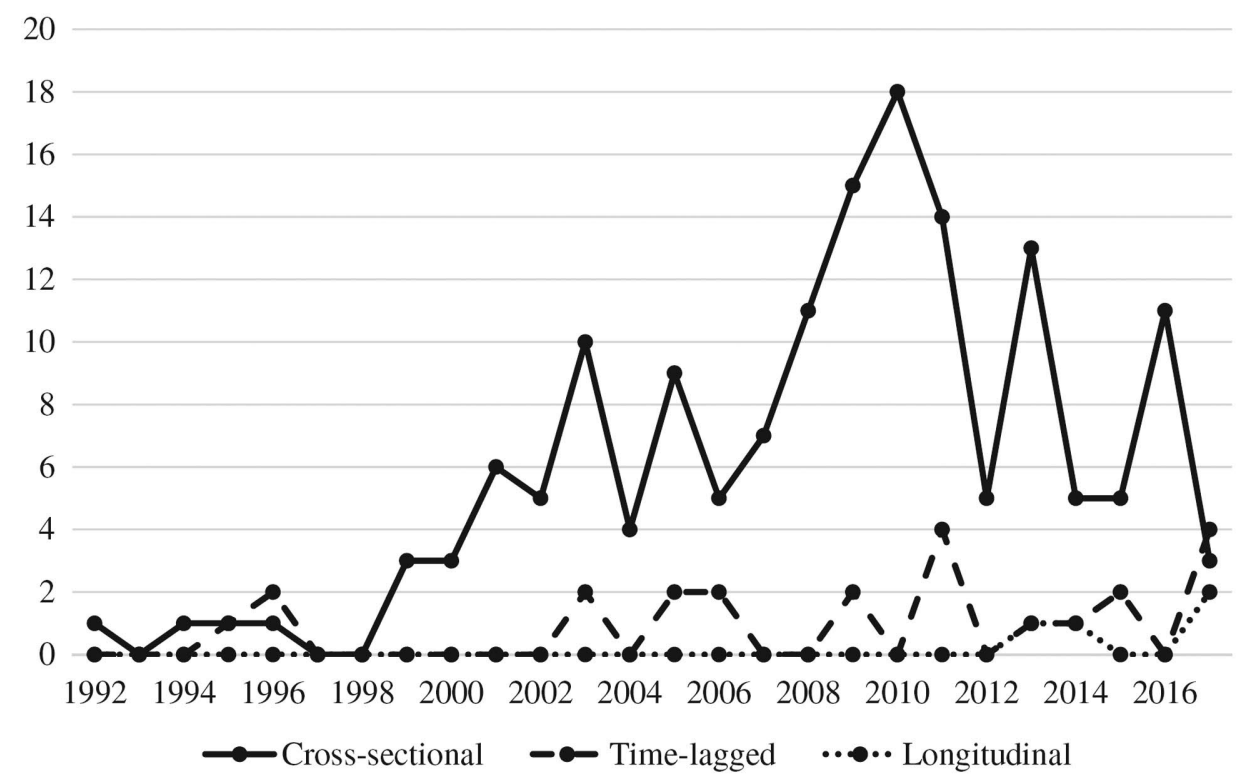

Figure 4. Numbers of Strategic HRM Studies by Research Design. 


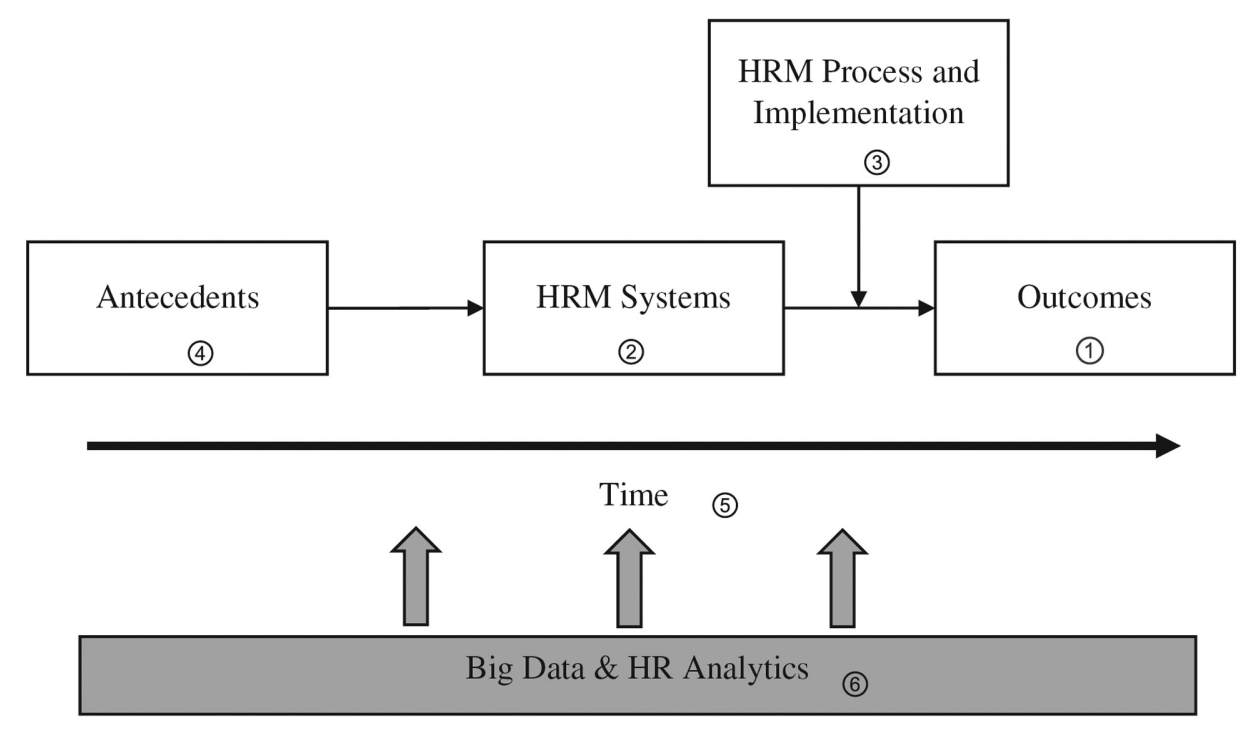

Figure 5. Future Directions of Strategic HRM Research.

However, studies using a time-lagged design have increased gradually, especially in the past ten years. Moreover, due to the availability of several longitudinal data sets, researchers have recently started to examine the longitudinal effects of HRM systems or the effects of the change in HRM systems on performance outcomes (e.g. DeGeest et al., in press; Kim \& Ployhart, 2013; Li, Wang, van Jaarsveld, Lee, \& Ma, in press; Piening et al., 2013; Shin \& Konrad, 2014). Compared with cross-sectional and time-lagged designs, longitudinal designs are helpful for drawing more rigorous conclusions on the causal relationships between HRM systems and performance outcomes.

\section{Advancing the field of strategic HRM}

As evidenced by this review, the growth; expansion; and enhancement of the field of strategic HRM has been substantial. Greater evidence now exists that the philosophies, practices and policies within the domain of the HRM function are important for building successful enterprises (Combs et al., 2006; Jiang et al., 2012b; Jackson et al., 2014). However, much work remains. We join with others in the field in noting the need to expand the strategic HRM paradigm through the use of 
stronger, richer, and more multi-level methods (i.e. Wright \& Nishii, 2012; Wright \& Ulrich, 2017); a greater focus on innovation and social responsibility (Jackson et al., 2014); stronger theoretical models for both explanation and prediction (Fleetwood \& Hesketh, 2008); and a continued refinement of the constructs leveraged in the field, particularly the core constructs of high involvement, high commitment, and high performance work systems (Gerhart, 2012). The latter deserves increased levels of scrutiny as successful explanation and prediction rests on using a similar core construct to fit the label across the field. As long as the field continues to accept multiple measures, the constructs remain ill-defined and hamper the rate of progress in the field.

In addition, we also call for greater research attention on six specific areas of research. First, we review the need for a greater understanding of employee outcomes in strategic HRM research. Second, we discuss the need for examining HRM systems from multiple perspectives. Third, we encourage more research to distinguish between the content and the process of HRM systems and examine the interaction between the two. Fourth, we address the need to continue to connect to internal and external characteristics of organizations to understand the origins and adoptions of HRM systems. Fifth, we discuss the need for integrating time into strategic HRM research to have a greater understanding of the dynamic processes of the antecedents and consequences of HRM systems overtime. Finally, we note the need for further research into workforce and HR analytics and applying 'big data' analytics into strategic HRM research. We address each of these core areas below.

\section{Employee outcomes \& positive organizational scholarship}

There continues to be a need in the field for a more diverse set of outcome measures that reflect the interests of multiple stakeholder

groups (Jackson et al., 2014). The field of strategic HRM has traditionally focused its efforts on understanding the effect of HR systems on measures of unit- and firm-performance. This focus is natural as it reflects the 'strategic' focus of the field. However, there has been a growing interest in understanding the effects such systems have on employee outcomes, particularly outcomes related to employee wellbeing (Boxall \& Macky, 2009; Van De Voorde et al., 2012). Research in 
this area has focused either on the 'conflicting gains' or 'mutual gains' models, where the association between firm performance outcomes and employee well-being is thought to be contradictory in the former literature or symbiotic in the latter literature (Godard, 2001; Jensen et al., 2013; Ramsay et al., 2000; Van De Voorde et al., 2012; Wall \& Wood, 2005). In a recent review of this literature, Van De Voorde et al. (2012) found mixed results for employee well-being, depending upon whether studies examine happiness-, relational-, or health-related well-being, with the former two measures relating positively to organizational performance and the latter seeming to fall more in line with the 'conflicting' gains model.

The lack of clarity in this literature clearly demonstrates a need for greater attention to the question of employee well-being. Scholars in this domain have the opportunity to look to recent work in positive organizational scholarship (POS) (Cameron et al., 2003; Luthans, 2002) to develop a more robust theory in relation to the connection between HR systems and employee well-being and the extent to which these factors relate to the performance of the firm. Leveraging models of self-determination theory (Deci \& Ryan, 1985; Deci et al., 1989) may offer guidance to scholars as they seek to understand the connection between complex organizational systems (i.e. HPWSs) and individual experiences of autonomy and self-regulation. The relationships are not straightforward. Tensions likely exist within HR systems that seek to promote aspects of both intrinsic (i.e. job autonomy) and extrinsic (i.e. pay-for-performance) motivations simultaneously. In fact, many measures of HPWS consider both types of factors simultaneously and assume an overall positive effect on motivation. This may be the case, or it may be that certain practices actually cancel each other out, leading to neutral or negative outcomes for employee well-being. Another possibility is that HPWS may have a curvilinear relationship with employee well-being such that HPWS may enhance employee well-being by providing support and resources to employees but after a certain level the positive effect of HRM systems may be offset by the increasing demands of HPWS on employees. Future work is needed to better understand these linkages.

Similarly, the field may benefit from greater understanding of psychological capital, including the relationship between important psychological resources like hope, optimism, resilience, and efficacy 
(Luthans et al., 2007; Luthans \& Youssef- Morgan, 2017). Developments in the area of POS and psychological capital may offer a richer understanding of the employee experience at work and are likely to interact with important elements of the HR system both positively and negatively. Greater attention needs to be paid to some of these important within-person effects in the field, while also maintaining a lineof-sight with how such systems go on to affect firm performance. In the end, finding avenues to promote both organizational success and employee well-being simultaneously will place the field on a sustainable path.

\section{Multiple perspectives of HRM systems}

Strategic HRM research has traditionally examined HRM systems from the management perspective by asking managers to report the use of HRM systems in organizations. Recent research has started to assess HRM systems from both employee and management perspectives and found interesting results. First, employees may have different perceptions of HRM systems from their managers' (e.g. Liao et al., 2009; Nishii \& Wright, 2008) and different perceptions may also exist among employees within the same organization (e.g. Jiang, Hu, Liu, \& Lepak, 2017). Second, it is employees' perceptions of HRM systems that have more direct relationships with employee outcomes than manager-reported HRM systems (e.g. Aryee et al., 2012; Den Hartog et al., 2013; Jensen et al., 2013). This stream of research highlights the importance of understanding multiple perspectives of HRM systems and suggests several directions of strategic HRM research.

First of all, scholars need to pay more attention to understanding how employees form their perceptions of HRM systems and what factors may influence their perceptions of HRM systems. Researchers can draw upon social cognition theories (Fiske \& Taylor, 1991) to examine how the features of HRM systems affect HRM information conveyed to employees and explain why employees attend to different aspects of the information. Scholars can also base on social influence theories (Levy, Collins, \& Nail, 1998) to study how the characteristics of supervisors and peers affect focal employees' perceptions of HRM systems. The answers to these questions can help scholars understand the source of the variability in perceptions of HRM systems and help 
practitioners understand how to align different employees' perceptions with actual HRM systems or perceptions of managers.

In addition to understanding the cause of different perceptions of HRM systems, it is also worth examining the consequences of HRM systems measured from different perspectives. Previous research has found that employees' perceptions of HRM systems mediate the relationships between manager-rated HRM systems and employee outcomes, suggesting that HRM systems rely on employees' perceptions and interpretations to make an impact (e.g. Aryee et al., 2012; Den Hartog et al., 2013; Jensen et al., 2013). But research has also revealed that HRM systems may have a direct impact on certain types of outcomes regardless of employees' perceptions. For example, Liao and colleagues (2009) found a direct relationship between manager-rated HPWS and employee human capital after controlling for employees' perceptions of HPWS. To reconcile the inconsistent findings, researchers can continue to examine the mediating role of employees' perceptions for different outcomes or take a congruence approach (e.g. polynomial regression) to examine the consequences of the alignment or misalignment between employees' and managers' perceptions of HRM systems. The findings can advance our understanding of the roles of HRM systems measured from multiple perspectives in affecting different types of outcomes.

\section{Process and implementation of HRM systems}

Bowen and Ostroff (2004) distinguished between the content and the process of HRM systems and suggested that an HRM system can only affect employee attitudes and behaviors in an expected way when the system is delivered to send unambiguous signals to employees. They proposed the construct of the strength of the HRM system and believed that organizations need to develop a strong HRM system in order to make it have its intended consequences. However, after a decade since the initial publication of their theoretical paper, how the HRM process affects the effects of an HRM system still remains largely underexplored (Ostroff \& Bowen, 2016). We concur with these scholars that not all HRM systems are perfectly delivered to send intended messages to employees. Future research needs to develop a valid measure to assess the mechanism through which HRM systems 
are implemented in organizations and examine the extent to which the effects of HRM systems are dependent on the HRM process.

Similarly, Nishii and Wright (2008) proposed a process model of strategic HRM and noted that there are gaps between intended and implemented HRM systems and between implemented and perceive HRM systems. Their model also underscores the important role of implementation in translating the intended HRM systems to employees' perceptions. Based on their model, some researchers focused on the role of line managers who are directly responsible for implementing HRM systems (e.g. Bos-Nehles, 2010; Den Hartog et al., 2013; Jiang et al., 2013; Sikora et al., 2015). Future research may follow this stream of work to explore how line managers' characteristics (e.g. abilities and motivation) and their interactions with HRM departments and employees (e.g. collaboration and communication) may influence HRM implementation effectiveness, and eventually examine how these factors may affect the relationships between HRM systems and outcomes. This is an important and needed step in the field. In order to offer more robust and predictive models of success from HRM systems, the mechanisms needed to translate strategic intent to practice are paramount to the advancement of the field.

\section{Antecedents of HRM systems}

Jackson and colleagues (2014) defined strategic HRM research as the study of HRM systems and their interrelationships with other elements comprising an organizational system. While the field has significantly benefited from the progress made in understanding the relationships between HRM systems and outcomes (Combs et al., 2006; Jiang et al., 2012b), considerably less effort has been spent theorizing and examining the relationships between HRM systems and other factors of organizations. In particular, the field lacks a body of work examining the antecedents of HRM systems. For example, while the field bears the name 'strategic,' the reality is that there is much ground to still explore in drawing out understandings about the connections between firm strategy and HRM systems. We consider this an important area of inquiry for the field moving forward as it may help understand why firms adopt different types of HRM systems or why not all firms use HPWS given the substantial returns to HPWS (Huselid \& Becker, 2011). 
Scholars can follow early models of strategic HRM (e.g. Jackson \& Schuler, 1995; Wright \& McMahan, 1992) to examine how the internal (e.g. firm characteristics) and external environments (e.g. industry characteristics and technologies) shape the adoption of HRM systems. Moreover, researchers can focus on the decision-making process of firm leaders and entrepreneurs to get a better sense of why they choose to implement HRM systems. Are they implemented to meet regulatory demands, to drive performance, to better divide labor, or simply as an isomorphic response to industrial forces? Further, what are the roles of managerial perceptions in this process? Are there heuristics that prevent managers from adopting HR systems or are their perspectives on the employees themselves that make it more or less likely for managers to adopt a system of practices? More systematic studies of the antecedents and origins of HRM systems will likely prove fruitful to both theory and practice.

\section{Time issue and causality}

While numerous studies have linked greater investments in human capital and HRM systems to firm performance outcomes, the field still lacks a body of longitudinal work that can more rigorously test causality (Wright \& Ulrich, 2017). This will continue to remain an important research area to move the field forward. In particular, studies on young or small firms that adopt HPWS at various stages of development ought to be tracked to gain a stronger sense of the causal relationship between HPWS and performance. While some work has been done through the Stanford Project on Emerging Companies (Baron et al., 1996) and the Kauffman Firm Survey (DeGeest et al., in press), and through Welbourne's work on IPO firms (Welbourne \& Andrews, 1996), more work is needed in tracking young firms over time to get a sense of when high involvement or high performance work practices are implemented, why they are implemented, how they are implemented and the resultant performance of these firms over time. A better understanding of this emergence process will provide stronger evidence for the causal pathways linking HR systems and firm performance (Jackson et al., 2014). In addition, researchers may conduct field experimental studies to explore how performance outcomes will change over time after the implementation of a new type of HRM 
system. Such an effort will likely require a tremendous investment of resources and time, but the pay-off for the field may be substantial.

In addition to longitudinal studies assessing origins and causality, it would also be instructive to understand the on-going returns of HPWS. If the system is seen to be a benefit to the firm, do these benefits continue over time, or are they reflected in short-term productive gains? The expectation of enhancing the ability, motivation, and opportunity to contribute to the workforce is that performance will continue to advance; however, there will naturally be limits to the performance levels that firms are able to achieve. Studies of comparative advantage are likely needed to determine the sustainability of human and social capital based advantages in the marketplace. Similarly, questions arise about performance variability. Depending upon the industrial context, employees who are given greater flexibility and autonomy are likely to produce more innovative and creative outcomes. Innovation often brings risk and variability in performance. Understanding the nature of the relationship between HPWS, important mediators and performance variability over time will help to uncover these effects.

\section{Big data \& HR analytics}

Strategic HRM field has much benefited from the development of research methods in the past two decades. For example, multilevel analysis has stimulated multilevel thinking in strategic HRM and promoted multilevel research examining the crosslevel effects of HRM systems on individual outcomes (e.g. Liao et al., 2009). Latent growth modeling has also advanced the understanding of longitudinal effects of HRM systems over time (e.g. Kim \& Ployhart, 2014). In the future, we believe that the field of strategic HRM will continue to evolve with the development of more advanced analytical techniques. Especially, HR analytics and 'big data' have increasingly become pervasive topics in both business and the academy, which provides new opportunities to examine the main research questions of strategic HRM discussed above. For example, researchers may use data scraping technique to automatically identify and collection information about HRM systems from organizations' webpages or social media and apply topic analyses to analyze the content of HRM systems. This may become a novel approach to measuring HRM systems and collect HRM information of 
much more companies than the traditional survey approach. For another instance, researchers may rely on new technologies (e.g. smart watches, smart phones, eye trackers, and other sensors) to constantly collect employee behavior and well-being data and use machine learning techniques to analyze and predict how employees adapt to the changes in HRM systems.

However, although using big data and HR analytics for promoting business success and demonstrating the value of HR investments seems promising (Davenport et al., 2010), the research base to support the promise of big data and HR analytics is still limited (Rasmussen \& Ulrich, 2015). Similarly, practitioners often have to make decisions without the benefit of evidence or data to support the decision-making process (Rousseau \& Barends, 2011). This represents a clear area for further research testing and development. As noted by Angrave et al. (2016), academics will likely have a key part to play in continuing to advance the knowledge of HR analytics, which can be useful for organizations, and also in the actual implementation of the tools and techniques needed to analyze large datasets. Building connections between scholarship and practice at the nexus of big data analysis and decision-making will be important for the advancement of both. While scholars likely have the background needed to analyze and make sense of big data, practitioners play an important role in ensuring that the right questions are being asked to provide analytics that support the strategic initiatives of the organization (Angrave et al., 2016).

Related to the need to understand the impact of 'big data' on the field of strategic HRM is the importance of more accurately quantifying the costs of HRM system adoption. By and large, this has been a literature focused on the benefits of implementing forms of high involvement, commitment, or performance work practices. While Huselid's (1995) early work provided guidance on the practical improvements to bottom-line business performance, more work is needed on the cost side of the equation. Questions related to the implementation costs of HPWSs have largely gone unexplored. As such, it has been difficult to offer guidance on the return on investment that organizations should expect when implementing models of HPWSs in their organizations. These questions become increasingly important when the context of research in the field shifts to smaller or newer firms, or when considering businesses in emerging markets. What practices will provide the 
greatest value to these firms? Does a fully integrated set of selection, training, performance management, and compensation practices make sense in these contexts, or are there sets of more streamlined practices that are more beneficial in newer firms? Answering such questions will require the field to focus not only on the benefits, but also on the costs of implementing strategic HRM systems.

\section{Conclusion}

Over the past 30 years the attention given to the strategic role of HRM in organizations has been significant. The theoretical and empirical advancement of the field has enhanced the rigor of scholarship and the quality of conclusions that might be drawn from this field of study. However, much remains unknown. We hope this review can help to scholars to understand the primary theoretical frameworks, empirical findings, methodological challenges, and recent trends in strategic HRM research. We also hope that this article can provide insightful guidance for future strategic HRM research. The strategic management of human capital will likely be a defining mark of success in the twenty-first century, which calls for an increased focus on the philosophies, policies and practices leveraged to optimize HRs. Strategic HRM is well positioned to contribute to this discussion provided that the field continues to ask and answer research questions of value and strategic importance.

\section{Notes}

1. The supplementary material is available upon request.

2. The list of articles is available upon request.

Disclosure No potential conflict of interest was reported by the authors. 


\section{References}

All review articles reviewed in this paper were marked with an "asterisk".

Angrave, D., Charlwood, A., Kirkpatrick, I., Lawrence, M., \& Stuart, M. (2016). HR and analytics: Why HR is set to fail the big data challenge. Human Resource Management Journal, 26(1), 1-11.

Arthur, J. B. (1992). The link between business strategy and industrial relations systems in American steel minimills. ILR Review, 45, 488-506.

* Arthur, J. B., \& Boyles, T. (2007). Validating the human resource system structure: A levels-based strategic HRM approach. Human Resource Management Review, 17, 77-92.

Aryee, S., Walumbwa, F. O., Seidu, E. Y., \& Otaye, L. E. (2012). Impact of highperformance work systems on individual-and branch-level performance: test of a multilevel model of intermediate linkages. Journal of Applied Psychology, 97(2), 287-300.

Barney, J. (1991). Firm resources and sustained competitive advantage. Journal of Management, 17, 99-120.

Barney, J. B., \& Wright, P. M. (1998). On becoming a strategic partner: The role of human resources in gaining competitive advantage. Human Resource Management, 37(1), 31-46.

Baron, J. N., Burton, M. D., \& Hannan, M. T. (1996). The road taken: Origins and evolution of employment systems in emerging companies. Industrial and Corporate Change, 5, 239-275.

Becker, B., \& Gerhart, B. (1996). The impact of human resource management on organizational performance: Progress and prospects. Academy of Management Journal, 39, 779-801.

Becker, B. E., \& Huselid, M. A. (1998). High performance work systems and firm performance: A synthesis of research and managerial implications. In K. M. Rowland, \& G. R. Ferris (Eds.), Research in personnel and human resources management, 16 (pp. 53-101). Greenwich, CT: JAI.

Becker, B. E., \& Huselid, M. A. (2006). Strategic human resources management: where do we go from here? Journal of Management, 32, 898-925.

Blau, P. M. (1964). Exchange and power in social life. New York: John Wiley.

Boselie, P., Dietz, G., \& Boon, C. (2005). Commonalities and contradictions in HRM and performance research. Human Resource Management Journal, 15, 67-94.

Bos-Nehles, A. C. (2010). The line makes the difference: Line managers as effective HRM partners. Enschede: University of Twente.

Bowen, D. E. \& Ostroff, C. (2004). Understanding HRM-firm performance linkages: The role of the "strength" of the HRM system. Academy of Management Review, 29(2), 203-221.

Boxall, P., \& Macky, K. (2009). Research and theory on high-performance work systems: Progressing the high-involvement stream. Human Resource Management Journal, 19, 3-23. 
* Boxall, P., \& Purcell, J. (2000). Strategic human resource management: Where have we come from and where should we be going? International Journal of Management Reviews, 2, 183-203.

Boxall, P., \& Purcell, J. (2008). Strategy and human resource management (2nd ed.). Basingstoke: Palgrave MacMillan.

Cameron, K. S., Dutton, J. E., \& Quinn, R. E. (2003). An introduction to positive organizational scholarship. Positive organizational scholarship, 3, 3-13.

* Chadwick, C. (2010). Theoretic insights on the nature of performance synergies in human resource systems: Toward greater precision. Human Resource Management Review, 20, 85-101.

Chuang, C. H., \& Liao, H. (2010). Strategic human resource management in service context: Taking care of business by taking care of employees and customers. Personnel Psychology, 63, 153-196.

* Colakoglu, S., Hong, Y., \& Lepak, D. P. (2009). Models of strategic human resource management. The Handbook of Human Resource Management, 31-50.

* Colakoglu, S., Lepak, D. P., \& Hong, Y. (2006). Measuring HRM effectiveness: Considering multiple stakeholders in a global context. Human Resource Management Review, 16, 209-218.

Collins, C. J., \& Clark, K. D. (2003). Strategic human resource practices, top management team social networks, and firm performance: The role of human resource practices in creating organizational competitive advantage. Academy of Management Journal, 46, 740-751.

Combs, J., Liu, Y., Hall, A., \& Ketchen, D. (2006). How much do high-performance work practices matter? A meta-analysis of their effects on organizational performance. Personnel Psychology, 59, 501-528.

Davenport, T. H., Harris, J., \& Shapiro, J. (2010). Competing on talent analytics. Harvard Business Review, 88, 52-58.

Deci, E. L., \& Ryan, R. M. (1985). The general causality orientations scale: Selfdetermination in personality. Journal of Research in Personality, 19, 109-134.

Deci, E. L., Connell, J. P., \& Ryan, R. M. (1989). Self-determination in a work organization. Journal of Applied Psychology, 74, 580-590.

DeGeest, D. S., Follmer, E. H., Walter, S. L., \& O’Boyle, E. H. (in press). The Benefits of Benefits A Dynamic Approach to Motivation-Enhancing Human Resource Practices and Entrepreneurial Survival. Journal of Management.

Delery, J. E., \& Shaw, J. D. (2001). The strategic management of people in work organizations: Review, synthesis, and extension. In G. R. Ferris (Ed.), Research in personnel and human resource management, Vol. 20 (pp. 165-197). New York, NY: Elsevier Science.

Den Hartog, D. N., Boon, C., Verburg, R. M., \& Croon, M. A. (2013). HRM, communication, satisfaction, and perceived performance: A cross-level test. Journal of Management, 39, 1637-1665.

Dickmann, M., \& Müller-Camen, M. (2006). A typology of international human resource management strategies and processes. The International Journal of Human Resource Management, 17, 580-601. 
* Dyer, L., \& Reeves, T. (1995). Human resource strategies and firm performance: What do we know and where do we need to go? The International Journal of Human Resource Management, 6, 656-670.

Edwards, J. R. (2011). The fallacy of formative measurement. Organizational Research Methods, 14, 370-388.

* Ferris, G. R., Hochwarter, W. A., Buckley, M. R., Harrell-Cook, G., \& Frink, D. D. (1999). Human resources management: Some new directions. Journal of Management, 25, 385-415.

Fiske, S. T. \& Taylor, S. E. (1991). Social cognition. NY: McGraw-Hill.

Fleetwood, S., \& Hesketh, A. (2008). Theorising under-theorisation in research on the HRM-performance link. Personnel Review, 37, 126-144.

Gerhart, B. (2005). Human resources and business performance: Findings, unanswered questions, and an alternative approach. Management Revue, 16, 174-185.

Gerhart, B. (2007). Horizontal and vertical fit in human resource systems. Perspectives on Organizational Fit, 317-348.

Gerhart, B. (2012). Construct validity, causality, and policy recommendations: The case of high performance work practices systems. Human Resource Management Review, 22, 157-160.

Gerhart, B., Wright, P. M., \& McMahan, G. C. (2000). Measurement error in research on the human resources and firm performance relationship: further evidence and analysis. Personnel Psychology, 53, 855-872.

Godard, J. (2001). High performance and the transformation of work? The implications of alternative work practices for the experience and outcomes of work. ILR Review, 54, 776-805.

Gong, Y., Law, K. S., Chang, S., \& Xin, K. R. (2009). Human resources management and firm performance: The differential role of managerial affective and continuance commitment. Journal of Applied Psychology, 94, 263-275.

Gouldner, A. W. (1960). The norm of reciprocity: A preliminary statement. American Sociological Review, 161-178.

Guest, D. E. (1997). Human resource management and performance: A review and research agenda. The International Journal of Human Resource Management, 8, 263-276.

Guest, D. E. (2011). Human resource management and performance: Still searching for some answers. Human Resource Management Journal, 21, 3-13.

Guest, D. E. (2017). Human resource management and employee well-being: Towards a new analytic framework. Human Resource Management Journal, 27, 22-38.

Huselid, M. A. (1995). The impact of human resource management practices on turnover, productivity, and corporate financial performance. Academy of management journal, 38(3), 635-672.

Huselid, M. A., \& Becker, B. E. (2000). Comment on "Measurement error in research on human resources and firm performance: How much error is there and how does it influence effect size estimates?" by Gerhart, Wright, McMahan, and Snell. Personnel Psychology, 53, 835-854. 
Huselid, M. A., \& Becker, B. E. (2011). Bridging micro and macro domains: Workforce differentiation and strategic human resource management. Journal of Management, 37, 421-428.

Jackson, S. E., \& Schuler, R. S. (1995). Understanding human resource management in the context of organizations and their environments. Annual Review of Psychology, 46, 237-264.

Jackson, S. E., Schuler, R. S., \& Rivero, J. C. (1989). Organizational characteristics as predictors of personnel practices. Personnel Psychology, 42, 727-786.

Jackson, S. E., Schuler, R. S., \& Jiang, K. (2014). An aspirational framework for strategic human resource management. The Academy of Management Annals, $8(1), 1-56$.

Jensen, J. M., Patel, P. C., \& Messersmith, J. G. (2013). High-performance work systems and job control: Consequences for anxiety, role overload, and turnover intentions. Journal of Management, 39, 1699-1724.

* Jiang, K. (2016). Strategic human resource management and organizational commitment. In J. P. Meyer (Ed.), Handbook of Employee Commitment (pp. 289-304). Cheltenham: Edward Elgar Publishing.

Jiang, K., Lepak, D. P., Han, K., Hong, Y., Kim, A., \& Winkler, A. L. (2012). Clarifying the construct of human resource systems: Relating human resource management to employee performance. Human Resource Management Review, 22, 73-85.

Jiang, K., Lepak, D. P., Hu, J., \& Baer, J. C. (2012). How does human resource management influence organizational outcomes? A meta-analytic investigation of mediating mechanism. Academy of Management Journal, 55, 1264-1294.

Jiang, K., Takeuchi, R., \& Lepak, D. P. (2013). Where do we go from here? New perspectives on the black box in strategic human resource management research. Journal of Management Studies, 50, 1448-1480.

Jiang, K., Hu, J., Liu, S., \& Lepak, D. P. (2017). Understanding employees' perceptions of human resource practices: effects of demographic dissimilarity to managers and coworkers. Human Resource Management, 56(1), 69-91.

* Kaše, R., Paauwe, J., \& Batistič, S. (2014). In the eyes of Janus: The intellectual structure of HRM-performance debate and its future prospects. Journal of Organizational Effectiveness: People and Performance, 1, 56-76.

* Kaufman, B. E. (2012). Strategic human resource management research in the United States: A failing grade after 30 years? Academy of Management Perspectives, 26, 12-36.

* Kaufman, B. E. (2015a). Market competition, HRM, and firm performance: The conventional paradigm critiqued and reformulated. Human Resource Management Review, 25, 107-125.

* Kaufman, B. E. (2015b). The RBV theory foundation of strategic HRM: Critical flaws, problems for research and practice, and an alternative economics paradigm. Human Resource Management Journal, 25, 516-540.

* Kehoe, R. R. \& Collins, C. J. (2017). Human resource management and unit performance in knowledge-intensive work. The Journal of Applied Psychology, $102,1222-1236$. 
Kim, Y., \& Ployhart, R. E. (2014). The effects of staffing and training on firm productivity and profit growth before, during, and after the Great Recession. Journal of Applied Psychology,

* Kim, S., Wright, P. M., \& Su, Z. (2010). Human resource management and firm performance in China: A critical review. Asia Pacific Journal of Human Resources, 48, 58-85.

Klein, K. J., Conn, A. B., Smith, D. B., \& Sorra, J. S. (2001). Is everyone in agreement? An exploration of within-group agreement in employee perceptions of the work environment. Journal of Applied Psychology, 86, 3-16.

Kooij, D. T., Jansen, P. G., Dikkers, J. S., \& De Lange, A. H. (2010). The influence of age on the associations between HR practices and both affective commitment and job satisfaction: A meta-analysis. Journal of Organizational Behavior, 31, 1111-1136.

Lado, A. A., \& Wilson, M. C. (1994). Human resource systems and sustained competitive advantage: A competency-based perspective. Academy of management review, 19, 699-727.

Law, K. S., \& Wong, C. S. (1999). Multidimensional constructs M structural equation analysis: An illustration using the job perception and job satisfaction constructs. Journal of Management, 25, 143-160.

* Lengnick-Hall, M. L., Lengnick-Hall, C. A., Andrade, L. S., \& Drake, B. (2009). Strategic human resource management: The evolution of the field. Human Resource Management Review, 19, 64-85.

Lepak, D. P., \& Boswell, W. (2012). Strategic HRM and employee organizational relationship (EOR). Essays in Employee-Organization Relationships:

Applications for the 21st Century. New York, NY: Psychology Press/Routledge, 455-483.

Lepak, D. P., \& Shaw, J. D. (2008). Strategic HRM in North America: Looking to the future. The International Journal of Human Resource Management, 19, 1486-1499.

Lepak, D. P., \& Snell, S. A. (1999). The human resource architecture: Toward a theory of human capital allocation and development. Academy of management review, 24, 31-48.

Lepak, D. P., \& Snell, S. A. (2002). Examining the human resource architecture: The relationships among human capital, employment, and human resource configurations. Journal of Management, 28, 517-543.

Lepak, D. P., Liao, H., Chung, Y., \& Harden, E. E. (2006). A conceptual review of human resource management systems in strategic human resource management research. Research in personnel and human resources management (pp. 217-271). Bingley: Emerald Group Publishing Limited.

Lepak, D. P., Takeuchi, R., Erhardt, N., \& Colakoglu, S. (2006). Emerging perspectives on the relationship between HRM and performance. In R. J. Burke, \& C. L. Cooper (Eds.), The human resources revolution: Why putting people first matters (pp. 31-54). Oxford: Elsevier. 
* Lepak, D. P., Jiang, K., Han, K., Castellano, W. G., \& Hu, J. (2012). Strategic HRM moving forward: What can we learn from micro perspectives. In G. P. Hodgkinson, \& J. K. Ford (Eds.), International review of industrial and organizational psychology, Vol. 27 (pp. 231-258). Manchester: Wiley-Blackwell.

* Lepak, D. P., Jiang, K., Kehoe, R. R., \& Bentley, S.(in press). Strategic human resource management and organizational performance. In Viswesvaran, C., Anderson, N., Ones, D. S., \& Sinangil, H. K. (Eds.), Handbook of Industrial Work and Organizational Psychology (Vol. 3). London: Sage.

* Lepak, D. P., Jiang, K., Ployhart, R. (in press). Chapter 1: HR strategy, structure, and architecture. Cooper, C., Sparrow, P. (Eds.), A research agenda for human resource management. Edward Elgar.

Levy, D. A., Collins, B. E., \& Nail, P. R. (1998). A new model of interpersonal influence characteristics. Journal of Social Behavior and Personality, 13(4), 715-733.

Li, Y., Wang, M., van Jaarsveld, D., Lee, G. K., \& Ma, D. (in press). From EmployeeExperienced High-Involvement Work System to Innovation: An EmergenceBased Human Resource Management Framework. Academy of Management Journal.

Liao, H., Toya, K., Lepak, D. P., \& Hong, Y. (2009). Do they see eye to eye? Management and employee perspectives of high-performance work systems and influence processes on service quality. Journal of Applied Psychology, 94, 371-391.

Luthans, F. (2002). The need for and meaning of positive organizational behavior. Journal of Organizational Behavior, 23, 695-706.

Luthans, F., \& Youssef-Morgan, C. M. (2017). Psychological capital: An evidencebased positive approach. Annual Review of Organizational Psychology and Organizational Behavior, 4, 339-366.

Luthans, F., Avolio, B. J., Avey, J. B., \& Norman, S. M. (2007). Positive psychological capital: Measurement and relationship with performance and satisfaction. Personnel Psychology, 60, 541-572.

MacKenzie, S. B., Podsakoff, P. M., \& Jarvis, C. B. (2005). The problem of measurement model misspecification in behavioral and organizational research and some recommended solutions. Journal of Applied Psychology, 90, 710-730.

Messersmith, J. G., Patel, P. C., Lepak, D. P., \& Gould-Williams, J. S. (2011). Unlocking the black box: Exploring the link between high-performance work systems and performance. Journal of Applied Psychology, 96, 1105-1118.

Nishii, L. H., \& Wright, P. (2008). Variability within organizations: Implications for strategic human resource management. In D. B. Smith (Ed.), The people make the place (pp. 225-248). Mahwah, NJ: Lawrence Erlbaum Associates.

Nishii, L. H., Lepak, D. P., \& Schneider, B. (2008). Employee attributions of the "why" of HR practices: Their effects on employee attitudes and behaviors, and customer satisfaction. Personnel Psychology, 61, 503-545.

* Nyberg, A. J., \& Wright, P. M. (2015). 50 years of human capital research: Assessing what we know, exploring where we go. Academy of Management Perspectives, 29, 287-295. 
Nyberg, A. J., Moliterno, T. P., Hale Jr, D., \& Lepak, D. P. (2014). Resource-based perspectives on unit-level human capital: A review and integration. Journal of Management, 40, 316-346.

Ostroff, C., \& Bowen, D. E. (2016). Reflections on the 2014 decade award: Is there strength in the construct of HR system strength? Academy of Management Review, 41, 196-214.

Paauwe, J. (2009). HRM and performance: Achievements, methodological issues and prospects. Journal of Management Studies, 46, 129-142.

Paauwe, J., \& Boselie, P. (2003). Challenging 'strategic HRM' and the relevance of the institutional setting. Human Resource Management Journal, 13, 56-70.

* Paauwe, J., \& Boselie, P. (2005). HRM and performance: What next? Human Resource Management Journal, 15, 68-83.

Peccei, R., \& Van De Voorde, R. K. (in press). The application of the multilevel paradigm in human resource management-outcomes research: Taking stock and going forward. Journal of Management,. 0149206316673720.

Piening, E. P., Baluch, A. M., \& Salge, T. O. (2013). The relationship between employees' perceptions of human resource systems and organizational performance: Examining mediating mechanisms and temporal dynamics. Journal of Applied Psychology, 98, 926-947.

Ployhart, R. E., \& Moliterno, T. P. (2011). Emergence of the human capital resource: A multilevel model. Academy of Management Review, 36, 127-150.

Ployhart, R. E., Nyberg, A. J., Reilly, G., \& Maltarich, M. A. (2014). Human capital is dead; long live human capital resources!. Journal of Management, 4O, 371-398.

Posthuma, R. A., Campion, M. C., Masimova, M., \& Campion, M. A. (2013). A high performance work practices taxonomy: Integrating the literature and directing future research. Journal of Management, 39, 1184-1220.

* Purcell, J. (1999). Best practice and best fit: Chimera or cul-de-sac? Human Resource Management Journal, 9, 26-41.

Rabl, T., Jayasinghe, M., Gerhart, B., \& Kühlmann, T. M. (2014). A meta-analysis of country differences in the high-performance work system-business performance relationship: The roles of national culture and managerial discretion. Journal of Applied Psychology, 99(6), 1011.

Ramsay, H., Scholarios, D., \& Harley, B. (2000). Employees and high-performance work systems: Testing inside the black box. British Journal of Industrial Relations, 38, 501-531.

Rasmussen, T., \& Ulrich, D. (2015). Learning from practice: How HR analytics avoids being a management fad. Organizational Dynamics, 44, 236-242.

Rogers, E. W., \& Wright, P. M. (1998). Measuring organizational performance in strategic human resource management: Problems, prospects and performance information markets. Human Resource Management Review, 8, 311-331.

Rousseau, D. M., \& Barends, E. G. (2011). Becoming an evidence-based HR practitioner. Human Resource Management Journal, 21, 221-235. 
Schuler, R. S. (1992). Strategic human resources management: Linking the people with the strategic needs of the business. Organizational Dynamics, 21, 18-32.

Schuler, R. S., \& Jackson, S. E. (1987). Linking competitive strategies with human resource management practices. Academy of Management Executive, 1, 207-219.

* Schuler, R. S., \& Jackson, S. E. (2005). A quarter-century review of human resource management in the US: The growth in importance of the international perspective. Management Revue, 11-35.

Schuler, R. S., \& Tarique, I. (2007). International human resource management: A North American perspective, a thematic update and suggestions for future research. The International Journal of Human Resource Management, 18, 717-744.

Schuler, R. S., Budhwar, P. S., \& Florkowski, G. W. (2002). International human resource management: review and critique. International Journal of Management Reviews, 4, 41-70.

Shaw, J. D., Dineen, B. R., Fang, R., \& Vellella, R. F. (2009). Employee-organization exchange relationships, HRM practices, and quit rates of good and poor performers. Academy of Management Journal, 52, 1016-1033.

Shin, D., \& Konrad, A. M. (2014). Causality between high-performance work systems and organizational performance. Journal of Management, 43, 973-997.

Sikora, D. M., Ferris, G. R., \& Van Iddekinge, C. H. (2015). Line manager implementation perceptions as a mediator of relations between highperformance work practices and employee outcomes. Journal of Applied Psychology, 100, 1908-1918.

* Snell, S. A., Youndt, M. A., \& Wright, P. M. (1996). Establishing a framework for research in strategic human resource management: Merging resource theory and organizational learning. In G. R. Ferris (Ed.), Research in personnel and human resources management (pp. 61-90). Greenwich, CT: JAI Press.

Subramony, M. (2009). A meta-analytic investigation of the relationship between HRM bundles and firm performance. Human Resource Management, 48, 745-768.

Takeuchi, R., Lepak, D. P., Wang, H., \& Takeuchi, K. (2007). An empirical examination of the mechanisms mediating between high-performance work systems and the performance of Japanese organizations. Journal of Applied Psychology, 92, 1069-1083.

Takeuchi, R., Chen, G., \& Lepak, D. P. (2009). Through the looking glass of a social system: cross-level effects of high-performance work systems on employees' attitudes. Personnel Psychology, 62(1), 1-29.

Tsui, A. S., Pearce, J. L., Porter, L. W., \& Tripoli, A. M. (1997). Alternative approaches to the employee-organization relationship: Does investment in employees pay off? Academy of Management Journal, 40, 1089-1121.

Van De Voorde, K., Paauwe, J., \& Van Veldhoven, M. (2012). Employee wellbeing and the HRM-organizational performance relationship: a review of quantitative studies. International Journal of Management Reviews, 14, 391-407. 
Wall, T. D., \& Wood, S. J. (2005). The romance of human resource management and business performance, and the case for big science. Human Relations, 58, 429-462.

* Way, S. A., \& Johnson, D. E. (2005). Theorizing about the impact of strategic human resource management. Human Resource Management Review, 15(1), 1-19.

Welbourne, T. M., \& Andrews, A. O. (1996). Predicting the performance of initial public offerings: should human resource management be in the equation? Academy of Management Journal, 39, 891-919.

Wernerfelt, B. (1984). A resource-based view of the firm. Strategic Management Journal, 5, 171-180.

* Wood, S. (1999). Human resource management and performance. International Journal of Management Reviews, 1, 367-413.

Wright, P. M. (2003). Next generation SHRM research: From covariation to causation. CAHRS Working Papers Series, https://hdl.handle.net/1813/77102

Wright, P. M., \& Boswell, W. R. (2002). Desegregating HRM: A review and synthesis of micro and macro human resource management research. Journal of Management, 28, 247-276.

Wright, P. M., \& Haggerty, J. J. (2005). Missing variables in theories of strategic human resource management: Time, cause, and individuals. Management Revue, 164-173.

Wright, P. M., \& McMahan, G. C. (1992). Theoretical perspectives for strategic human resource management. Journal of Management, 18, 295-320.

Wright, P. M., \& McMahan, G. C. (2011). Exploring human capital: Putting 'human' back into strategic human resource management. Human Resource Management Journal, 21, 93-104.

Wright, P. M., \& Nishii, L. H. (2012). Strategic human resource management and organizational behaviour: Exploring variance as an integrating framework. HRM and performance: Achievements and challenges (pp. 97-110).

* Wright, P. M., \& Sherman, W. S. (1999). Failing to find fit in strategic human resource management: Theoretical and empirical problems. Research in personnel and human resources management, 4, 53-74.

* Wright, P. M., \& Snell, S. A. (1991). Toward an integrative view of strategic human resource management. Human Resource Management Review, 1, 203-225.

Wright, P. M., \& Ulrich, M. D. (2017). A road well travelled: The past, present, and future journey of strategic human resource management. Annual Review of Organizational Psychology and Organizational Behavior, 4, 45-65.

Wright, P. M., McMahan, G. C., \& McWilliams, A. (1994). Human resources and sustained competitive advantage: A resource-based perspective. The International Journal of Human Resource Management, 5, 301-326.

Wright, P. M., Dunford, B. B., \& Snell, S. A. (2001). Human resources and the resource based view of the firm. Journal of Management, 27, 701-721. 
Wright, P. M., Gardner, T. M., Moynihan, L. M., Park, H. J., Gerhart, B., \& Delery, J. E. (2001). Measurement error in research on human resources and firm performance: Additional data and suggestions for future research. Personnel Psychology, 54, 875-901.

Wright, P. M., Gardner, T. M., Moynihan, L. M., \& Allen, M. R. (2005). The relationship between HR practices and firm performance: Examining causal order. Personnel Psychology, 58, 409-446.

* Wright, P. M., Snell, S. A., \& Dyer, L. (2005). New models of strategic HRM in a global context. The International Journal of Human Resource Management, 16, 875-881.

Zacharatos, A., Barling, J., \& Iverson, R. D. (2005). High-performance work systems and occupational safety. Journal of Applied Psychology, 90, 77-93. 